\title{
Stenospermy and seed development in the "Brazilian seedless" variety of sugar apple (Annona squamosa)
}

\author{
RAYANE C. DOS SANTOS ${ }^{1}$, LEONARDO M. RIBEIRO ${ }^{2}$, MARIA OLÍVIA MERCADANTE-SIMÕES ${ }^{2}$, \\ MÁRCIA R. COSTA ${ }^{1}$, SILVIA NIETSCHE ${ }^{1}$ and MARLON C.T. PEREIRA ${ }^{1}$ \\ ${ }^{1}$ Laboratório de Biotecnologia, Departamento de Ciências Agrárias, Unimontes, \\ Av. Reinaldo Viana, 2630, Campus Janaúba, 39440-000 Janaúba, MG, Brasil \\ ${ }^{2}$ Laboratório de Micropropagação, Departamento de Biologia Geral, Unimontes, \\ Av. Rui Braga, s/n, Campus Prof. Darcy Ribeiro, 39401-089 Montes Claros, MG, Brasil
}

Manuscript received on April 23, 2014; accepted for publication on June 30, 2014

\begin{abstract}
Stenospermy was identified in naturally occurring sugar-apple (Annona squamosa) mutants with great potential for use in genetic improvement programs. However, to date, there have been no detailed studies of the development of aspermic fruit in this species. The aim of the present study was to characterize the anatomy of developing fruit in the 'Brazilian Seedless' mutant. Flower buds in pre-anthesis and developing fruits were subjected to common plant anatomy techniques. The abnormal ovules are unitegmic and orthotropic and have a long funiculus. There is evidence of fertilization, including the presence of embryos in early development and the proliferation of starch grains in the embryo sac. However, the embryos and embryo sac degenerate, although this does not affect pericarp development. Ovule abortion does not occur. The perisperm, which is formed from the peripheral layers of the nucellus, fills the cavity left by the embryo sac. The mature fruit contains numerous small sterile seeds with abundant perisperm and unlignified integument that is restricted to the micropylar region. The majority of perisperm cells are living and appear to be metabolically active in the periphery. Therefore, stenospermy leads to the formation of sterile seeds in A. squamosa, and the perisperm possibly play an important role in fruit development.
\end{abstract}

Key words: Annonaceae, seedless fruits, fruit development, stenospermy, nucellus, perisperm.

\section{INTRODUCTION}

Annona squamosa L. (Annonaceae), also known as the sugar-apple, is a tropical species that produces fruits valued for their aroma and flavor (Pareek et al. 2011), which are used to manufacture juices, ice creams and jellies (Figure 1) (Donadio 1997, Araújo and Alves 1999). However, adoption of this fruit tree in the market remains limited, although its popularity could be expanded by developing varieties that are

Correspondence to: Leonardo Monteiro Ribeiro

E-mail: leomrib@hotmail.com more attractive to consumers (Manica 2003). In particular, one characteristic that is of great interest is aspermia, which has been reported for some naturally occurring mutants of A. squamosa (Araújo and Alves 1999, Manica 2003, Lora et al. 2011) and has shown economic significance in several species (Varoquaux et al. 2000, JinPing et al. 2009, Zhang et al. 2012).

A plant is considered aspermic if it produces fruits that are seedless, contain only the remnants of aborted seeds or contain only a very small number 
of seeds (Varoquaux et al. 2000). This condition can result from parthenocarpy, in which the ovary develops without ovule fertilization, or from stenospermy, in which the fruit contains partially formed seeds that were aborted after fertilization (Bouquet and Danglot 1996, Lora et al. 2011).
Lora et al. (2011) described an aspermic $A$. squamosa access originating from a spontaneous mutation referred to as 'Thai seedless'. This access produces seedless fruits of normal size, following pollination. The authors demonstrated that stenospermy in this mutant is due to suppression of the

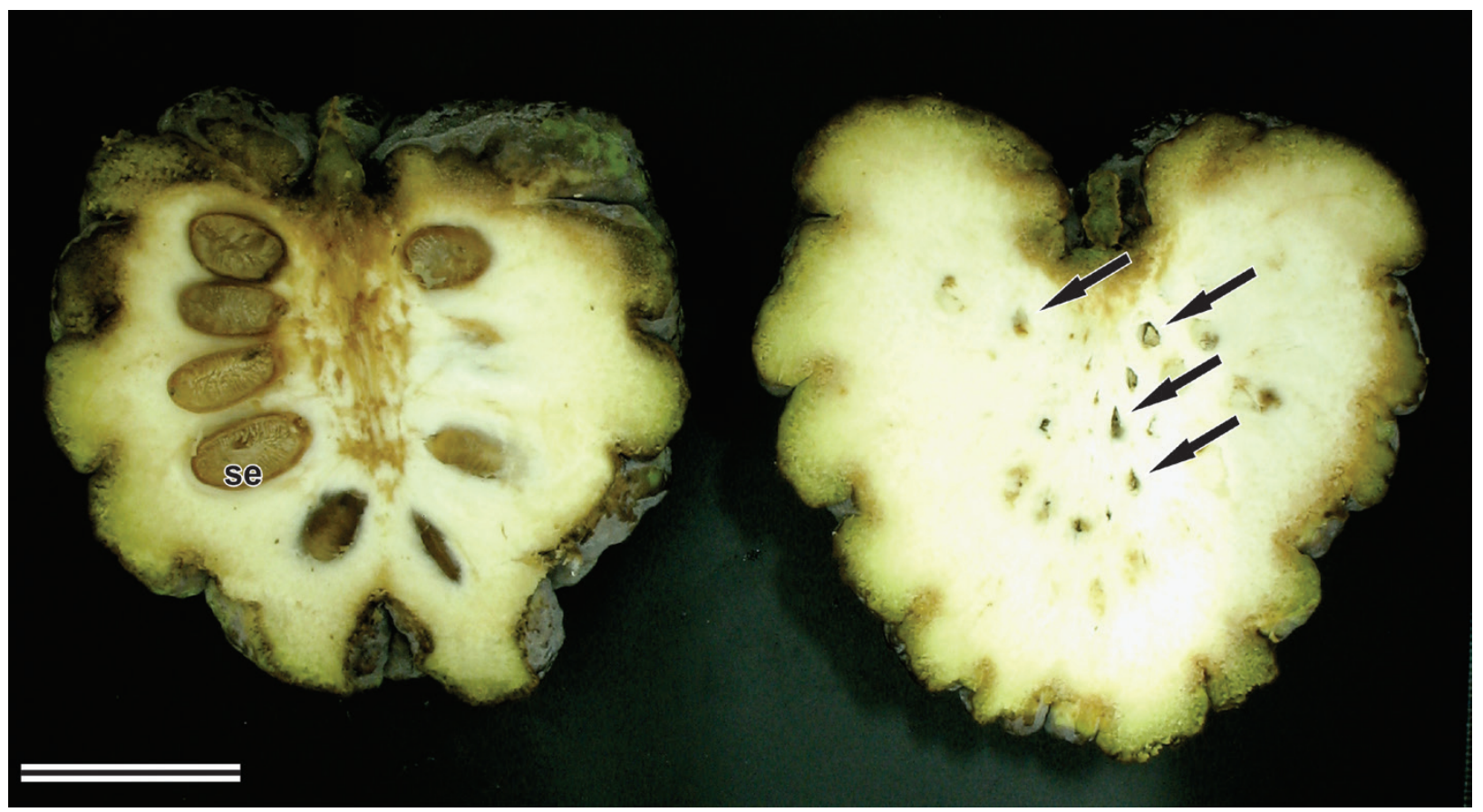

Figure 1 - Longitudinal sections of Annona squamosa fruits from normal (left) and aspermic mutant access, with the location of sterile seeds marked (arrows). se, seed. Scale bar: $3 \mathrm{~cm}$.

INO gene, leading to a loss of the outer integument of the ovule which affects the seed development. However, to date, there have been no detailed descriptions of the anatomy of developing aspermic fruit, and in particular, descriptions of ovule fate. As fruit development is commonly controlled by immature seeds (Taiz and Zeiger 2010), information on residual seminiferous structures could expand our knowledge concerning the formation of stenospermic fruit and aid in fruiting management. Moreover, it is unknown if this pattern of stenospermy (Lora et al. 2011) occurs more broadly in this species, and it may be responsible for other described cases of aspermia in the sugar apple (Araújo and Alves 1999, Manica 2003).
The aim of the present study was to describe the gynoecium and developing fruit in a Brazilian mutant of $A$. squamosa that produces aspermic fruits following pollination (Mendes et al. 2012) (Figure 1). In particular, we sought to answer the following questions: i) what type of aspermia is occurring and how similar is it to that observed in 'Thai seedless' mutant?; ii) what is the fate of the ovule?; and iii) is there evidence for the influence of residual seminiferous structures on fruit development?

\section{MATERIALS AND METHODS}

The plant material was collected from a natural mutant access of $A$. squamosa known as 'Brazilian seedless' from the Annonaceae orchard at 
the experimental field of the State University of Montes Claros (Universidade Estadual de Montes Claros - Unimontes) in the municipality of Janaúba, Minas Gerais, Brazil. Floral buds in pre-anthesis were collected, and the material was fixed in Karnovsky solution (Karnovsky 1965) for 48 hours and preserved in $70 \%$ alcohol (Jensen 1962). The flowers were artificially pollinated using pollen from wild-type plants with normal fruit, according to the methodology described by Mendes et al. (2012). Flowers were collected 24 hours after pollination, and developing fruit were collected at 48, 72 and 96 hours, and seven, ten, 15 and 90 (mature fruit) days after pollination. Flowers and fruits were sectioned to yield cubic fragments with edges measuring approximately 5 $\mathrm{mm}$. Fixation was performed as described for the flower buds. To serve as a reference, material was also obtained from a normal plant and processed as described above.

To prepare permanent slides, the material was dehydrated in a graded ethanol series and embedded in methacrylate (Leica ${ }^{\circledR}$ ), according to the protocol of Paiva et al. (2011). Serial longitudinal sections and cross-sections ( $6 \mu \mathrm{m}$ thick) were prepared using a rotary microtome. The sections were stained with $0.05 \%$ toluidine blue in acetate buffer $(\mathrm{pH} 4.7)$ (O’Brien et al. 1964) and mounted on slides with resin $\left(\right.$ Itacril $\left.{ }^{\circledR}\right)$. The slides were examined using a Zeiss Lab AI light microscope, and images were acquired digitally with a Zeiss Axion Cam ICc 3 camera.

\section{RESULTS}

The gynoecium is apocarpous with unicarpellate and unilocular superous ovaries, and the carpels are inserted spirally into the distal region of the conical receptacle (Figure 2A). The stigma and style feature secretory idioblasts and idioblasts with phenolic content, as well as long unicellular trichomes. The stigma is elongated and has approximately the same diameter throughout its length. A papillous tissue is present in the stylar channel.
The outer ovarian epidermis is uniseriate, composed of juxtaposed cuboidal cells with thin walls, slightly dense cytoplasm and distinct nuclei (Figure 2B). The ovarian mesophyll contains irregularly shaped parenchyma cells, idioblasts with phenolic content, and secretory idioblasts. The internal ovarian epidermis contains cells with similar characteristics to outer epidermal cells, but it also contains numerous papillae in the basal region near the funiculus and adjacent to the stylar channel.

There are commonly two ovules per locule (Figure 2B); the ovules are orthotropic with a long funiculus, have basal placentation and are unitegmic. The integument contains three to four cell layers. Cells of the external epidermis are more vacuolated and larger than other cells, being especially large in the micropylar region. Cells of the inner epidermis accumulate phenolic compounds. The nucellus features an epidermis and three to six layers of highly vacuolated cuboidal cells with thin walls.

Evidence of fertilization can be observed as of 24 hours after pollination, including embryos in early development and the first stages of endosperm formation, including with presence of intense starch grains associated with the polar nuclei (Figure 2C). The beginning of fruit formation can be observed 48 hours after pollination and is marked by the development of the pericarp from an expansion of the ovarian mesophyll, which is linked to the proliferation of secretory idioblasts and idioblasts with phenolic content (compare Figures 2A and 2D). Furthermore, the degeneration of the the stigma and style can be observed, which is associated with the accumulation of phenolic compounds and the formation of an abscission zone that promotes the separation of these structures from the rest of the fruit.

Seventy-two hours after pollination, the seed had grown due to cellular expansion in the nucellus, and the embryo remains conspicuous (Figure 3A). However, by seven days after pollination, degeneration of the embryo and endosperm is evident (Figure 3B). Ten days after pollination, nucellar 

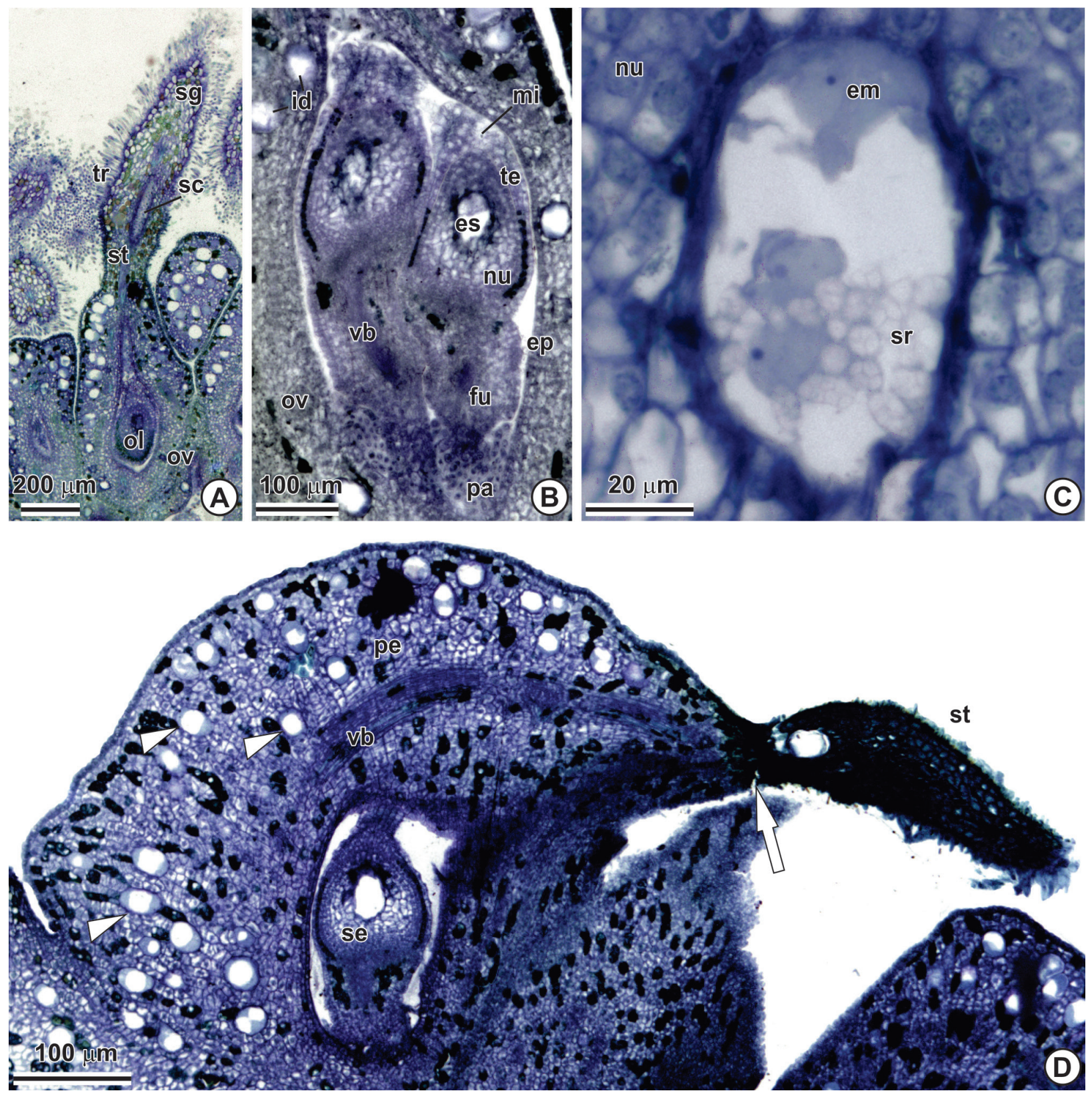

Figure 2 - Longitudinal sections of the gynoecium from an aspermic mutant of Annona squamosa. A flower carpel in pre-anthesis (A) and a detail of the ovary with two ovules (B). An ovule, $24 \mathrm{~h}$ after pollination, showing the embryo sac (C). The carpel, 48 $\mathrm{h}$ after pollination, showing the abscission zone of the style (arrow) and secretory idioblasts (arrowheads) (D). em, embryo; es, embryo sac; $f u$, funiculus; $i d$, secretory idioblast; ol, ovule; ov, ovary; $m i$, micropyle; $n u$, nucellus; pa, papillae; pe, pericarp; se, seed; $s c$, stylar channel; sg, stigma; $s r$, starch grain; $s t$, style; $t e$, integument; $t r$, trichomes; $v b$, vascular bundle.

meristematic activity can be observed in the chalazal region (Figure 3C). Fifteen days after pollination, meristematic activity is intense in the periphery of the nucellus, leading to the formation of the perisperm. The cells originated exhibit significant expansion and begin to occupy the space left by the embryo sac (Figure 3D).

Numerous seeds measuring approximately $7 \mathrm{~mm}$ in length are present within the mature fruit 90 days after pollination (Figures 1, 4A). These 

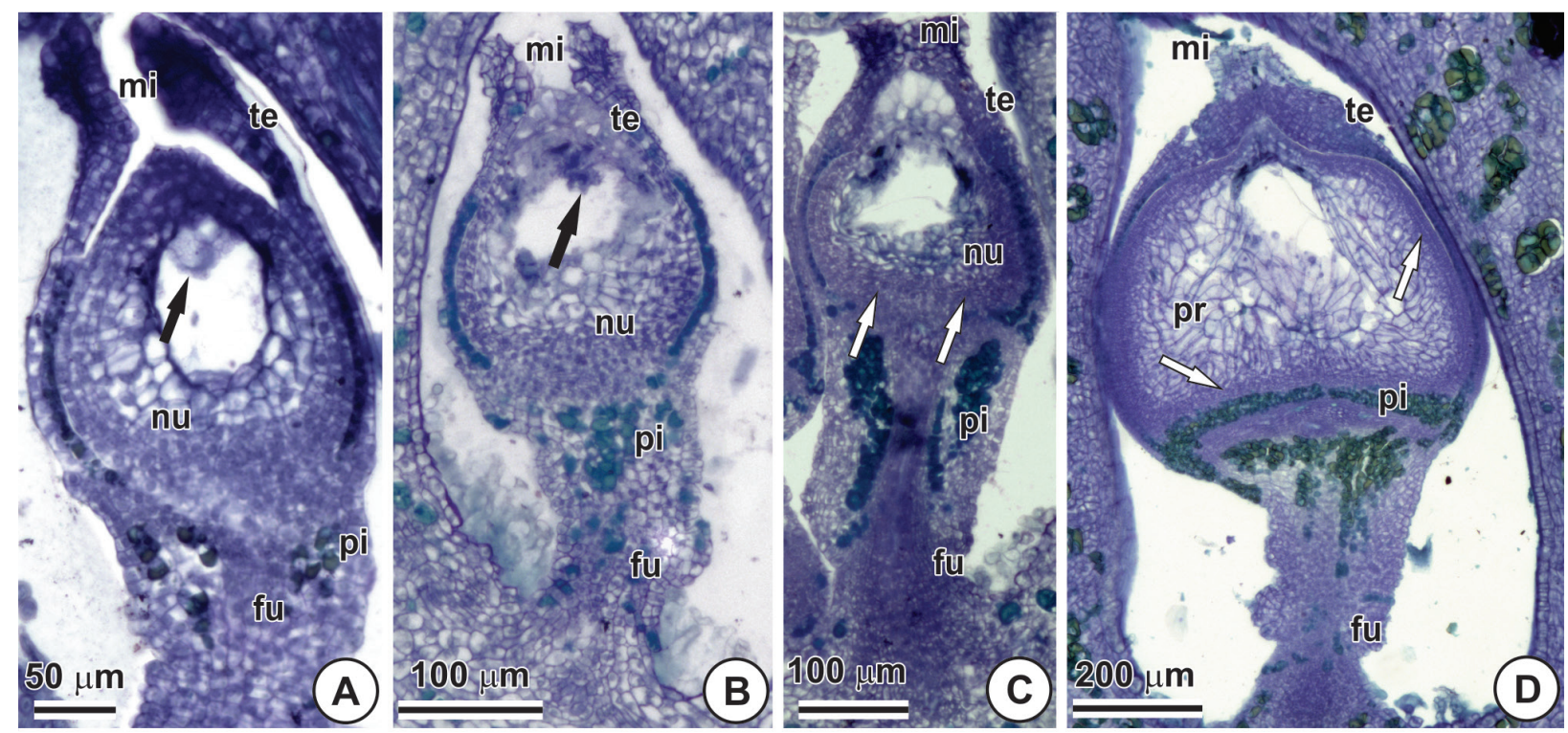

Figure 3 - Longitudinal sections of a seed from an aspermic mutant of Annona squamosa at different stages. Seventy-two hours after pollination, showing an embryo in early development (arrow) (A). Seven days after pollination, showing a degenerating embryo (arrows) (B). Ten days after pollination, showing meristematic activity in the nucellus (arrow) (C). Fifteen days after pollination, showing meristematic activity in the peripheral region of the nucellus (arrows) (D). fu, funiculus; $m i$, micropyle; $n u$, nucellus; $p i$, idioblasts with phenolic content; $p r$, perisperm; te, integument.

seeds are approximately 12 times longer than the ovule. The sterile seeds are formed from a persistent and extremely long funiculus and a wide perisperm, forming a globular portion with a vascularized central column and an apical micropylar region (Figure 4B). The integument persists only in the micropylar region, which is highly vascularized and features the accumulation of phenolic compounds (Figures 4BC). Residues of the integument are evident adjacent to the apical region of the perisperm, indicating that the integument does not develop, which results in its rupture (Figure 4B). The absence of integument development around the perisperm gives the seed a whitish color and smooth consistency (Figure 4A). Perisperm cells are parenchymatous with a gradient of differentiation toward the center (Figure 4B). In the peripheral region, cells are irregularly shaped with a tendency towards globular shapes, with prominent nuclei and dense cytoplasm, suggesting they are metabolically active (Figures 4B, D). In the central region, parenchyma cells are elongated and vacuolated (Figures 4B, E-F). The vascular column is formed by xylem and phloem, and their respective tracheary and sieve elements can be observed (Figure $4 \mathrm{~F}$ ) extending to the micropylar region (Figure 4B). The funiculus and the vascular column consist of parenchyma cells interspersed with sclereids and idioblasts with phenolic content (Figure 4G).

\section{DISCUSSION}

Aspermia in this 'Brazilian seedless' mutant is of the stenospermy type and may be related to suppression of the INO gene. In the 'Thai seedless' mutant, the absence of seeds is due to loss of the outer integument resulting from disruption or deletion of the INO locus (Lora et al. 2011). Although the extent of the deletion/disruption in the INO locus is unknown, it is likely that the absence of seeds in the 'Thai seedless' mutant is controlled by a single recessive gene, as all offspring ( $\mathrm{F} 1$ progeny) from a cross between wild type ( $A$. cherimola) and seedless mutants produce fruit with seeds. Recently, crosses performed between the 'Brazilian seedless' mutant and wild-type 


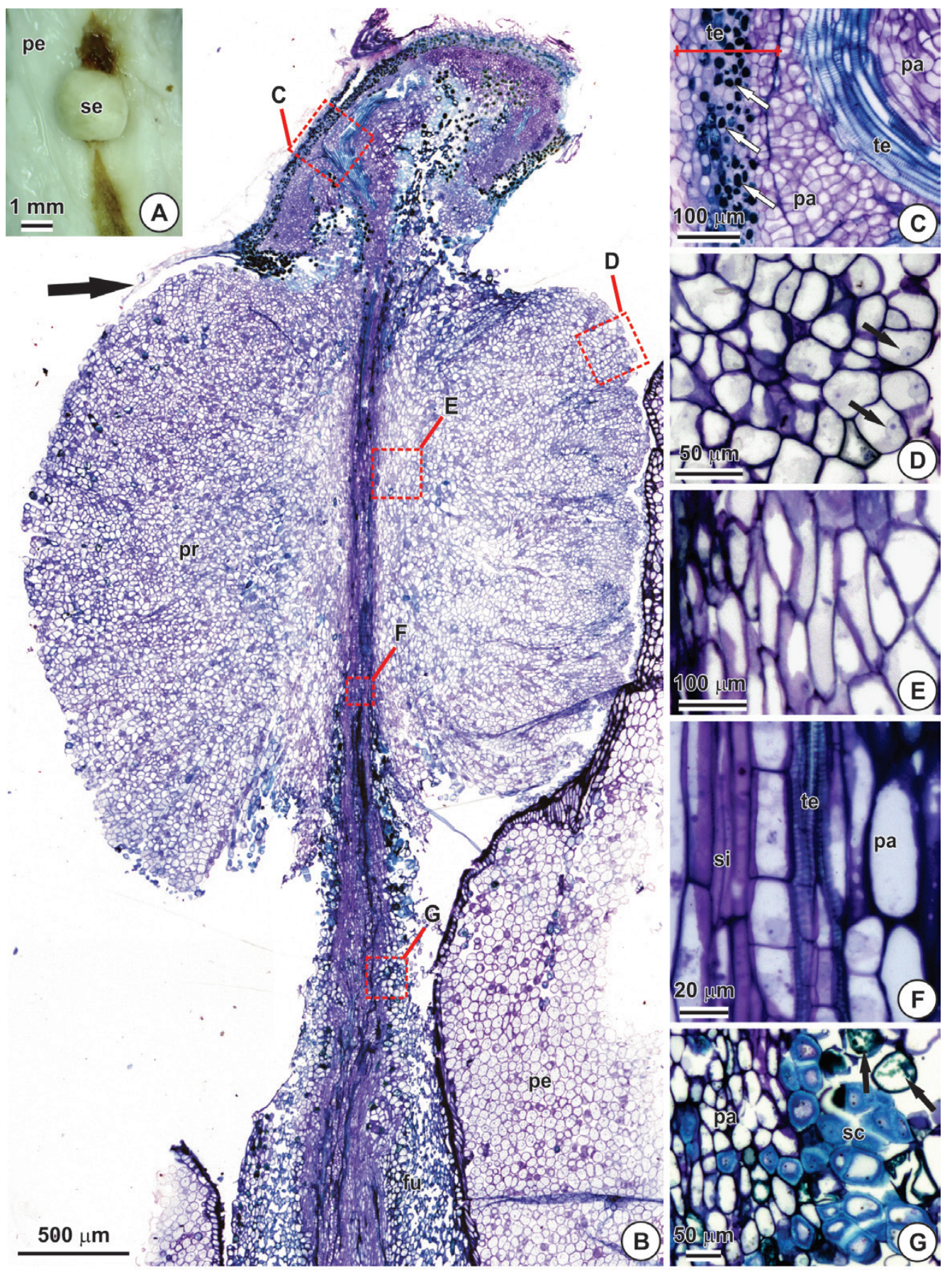

Figure 4 - Sterile seeds from the mature fruit of an aspermic Annona squamosa mutant. External appearance in lateral view (A). Longitudinal section, showing the site of integument rupture (arrow) and detailed regions in C-G (outlined boxes) (B). Micropylar region showing idioblasts with phenolic content (arrows) and the extension of the integument (red line) (C). Peripheral region of the perisperm highlighting prominent nuclei in cells with dense cytoplasm (arrows) (D). Elongated parenchyma cells in the central region of the perisperm $(\mathbf{E})$. The vascular column in the central region of the perisperm $(\mathbf{F})$. Middle region of the funiculus, featuring idioblasts with phenolic content (arrows). $p a$, parenchyma cells; $p e$, pericarp; $p r$, perisperm; sc, sclereids; se, seed; si, sieve elements; te, tracheal elements. 
Annona squamosa also indicated that this trait is recessive in nature (S. Nietsche et al., unpublished data). Furthermore, the dependence on pollination (Mendes et al. 2012), the production of fruits of normal shape and size, the peculiar structure of the ovule, the occurrence of fertilization and embryo degeneration in the 'Brazilian Seedless' mutant are all similar to descriptions of the stenospermic 'Thai seedless' access (Lora et al. 2011). The majority of gynoecium characteristics observed in the present study are typical of Annonaceae (Svoma 1998b, Judd et al. 1999) and were observed in the normal reference variety. However, the gynoecia of normal plants typically have an anatropous bitegmic ovule with a short funiculus (Corner 1976, Lora et al. 2011), whereas the aspermic mutant has an orthotropic unitegmic ovule and a long funiculus, which can be considered as morphological evidence of INO gene suppression (Lora et al. 2011).

Stenospermy in A. squamosa leads to the development of sterile seeds, which may play an important role in fruit development. Lora et al. (2011) suggest that stenospermy in this species may be associated with embryo or ovule abortion, although the authors did not describe the fate of these structures during fruit development. In the present study, following degeneration of the embryo and embryo sac, we observed proliferation of the nucellus and formation of an abundant perisperm with live peripheral cells that appeared metabolically active, even in mature fruit. Hormonal control of pericarp formation generally involves stimulation by auxin provided by developing seeds (Taiz and Zeiger 2010). It is possible that this also occurs in aspermic A. squamosa fruits, which could explain the dependence of fruit development on pollination (Mendes et al. 2012).

The aspermic nature of fruits from the 'Brazilian seedless' mutant is related to the lack of an outer integument in the ovule and rupturing of the inner integument adjacent to the perisperm. The stiffness of the seminal covering observed in A. squamosa and other Annonaceae species is due to the development of the external integument, which becomes lignified with a slightly stratified inner integument formed by invaginations associated with rumination of the endosperm (Svona 1998a). In the aspermic variety, intense perisperm growth promotes rupturing of the surrounding integument, giving the sterile seed a smooth, non-ruminate consistency and making it undetectable when the fruit is consumed. Future studies could test whether sterile seed development is common among other cases of aspermia in A. squamosa and determine how sterile seeds physiologically influence fruit development.

From the results of this study, we conclude that stenospermy in A. squamosa leads to the development of sterile seeds, which could play an important role in fruit development.

\section{ACKNOWLEDGMENTS}

The authors would like to thank the Fundação de Apoio à Pesquisa do Estado de Minas Gerais (FAPEMIG) for granting the BIPDT scholarship to L.M. Ribeiro, M.O. Mercadante-Simões, S. Nietsche and M.C.T. Pereira. The authors also thank the Conselho Nacional de Desenvolvimento Científico e Tecnológico (CNPq) for financial support.

\section{RESUMO}

A estenospermia foi identificada em mutantes naturais de fruta do conde (Annona squamosa) e tem grande potencial de uso em programas de melhoramento genético. Até agora, não existem estudos detalhados sobre o desenvolvimento dos frutos aspérmicos desta espécie. O objetivo deste trabalho foi caracterizar a anatomia do fruto em desenvolvimento no mutante 'Brazilian seedless'. Botões florais em pré-antese e frutos ao longo do desenvolvimento foram submetidos a técnicas usuais em anatomia vegetal. Os óvulos peculiares são unitegumentados, ortótropos e apresentam funículo longo. Existe evidência da fecundação como presença de embriões em início de desenvolvimento e proliferação de grãos de amido no saco embrionário. No entanto, os embriões e o saco embrionário degeneram, o que não 
afeta o desenvolvimento do pericarpo. Não ocorre aborto de óvulos e o perisperma, formado a partir das camadas periféricas do nucelo, preenche a cavidade deixada pelo saco embrionário. No fruto maduro ocorrem numerosas e pequenas sementes estéreis com abundante perisperma, porém, com tegumento não lignificado e restrito à região micropilar. A maioria das células do perisperma são vivas e têm aparência de serem metabolicamente ativas na periferia. A estenospermia leva a formação de sementes estéreis em A. squamosa e o perisperma possivelmente tem papel determinante no desenvolvimento do fruto.

Palavras-chave: Annonaceae, frutos sem sementes, desenvolvimento do fruto, estenospermia, nucelo, perisperma.

\section{REFERENCES}

ARAÚJO JF AND ALVES AAC. 1999. Instruções técnicas para o cultivo da pinha (Annona squamosa L.). Salvador: EBDA, 44 p.

BOUQUET A AND DANGLOT Y. 1996. Inheritance of seedlessness in grapevine (Vitis vinifera L.). Vitis 35: 35-42.

CORNER EJH. 1976. The seeds of dicotyledons. Cambridge: University Press, $558 \mathrm{p}$.

DoNADIO LC. 1997. Situação atual e perspectivas das anonáceas. In: SÃO JOSÉ AR, SOUZA IVB, MORAIS OM AND REBOUÇAS TNH (Eds), Anonáceas: produção e mercado (pinha, graviola, atemóia e cherimóia), Vitória da Conquista: Editora Universidade Estadual do Sudoeste da Bahia, p. 1-4.

JENSEN WA. 1962. Botanical histochemistry: principles and practice. San Francisco: W.H. Freeman, 408 p.

JinPING X, Ligeng C, Ming X, HAILIN L AND WEIQI Y. 2009. Identification of AFLP fragments linked to seedlessness in Ponkan mandarin (Citrus reticulata Blanco) and conversion to SCAR markers. Sci Hort 121: 505-510.

JudD WS, CAMPBELl PS, KELlOGG EA AND STEVENS PF. 1999. Plant systematics: a phylogenetic approach. Sunderland: Sinauer Associates, Inc. Publishers, 620 p.
KARNOVSKY MJ. 1965. A formaldehyde-glutaraldehyde fixative of high osmolality for use in electron microscopy. J Cell Biol 27: 137-138.

Lora J, Hormaza JI, Herrero M AND Gasser CS. 2011. Seedless fruits and the disruption of a conserved genetic pathway in angiosperm ovule development. PNAS 108: 5461-5465.

MANICA I. 2003. Frutas Anonáceas: Ata ou Pinha, Atemólia, Cherimólia e Graviola. Tecnologia de produção, Póscolheita e Mercado. Porto Alegre: Cinco Continentes, 596 p.

Mendes HTA, Costa MR, Nietsche S, Oliveira JAA AND PEREIRA MCT. 2012. Pollen grain germination and fruit set in 'Brazilian seedless' sugar apple (Annona squamosa L.). Crop Breeding and Appl Biotech 12: 277-280.

O'BrIEN TP, FEDER N AND MCCUlLY ME. 1964. Polychromatic staining of plant cell walls by toluidine blue $\mathrm{O}$. Protoplasma 59: 368-373.

Paiva EAS, Pinho SZ AND OliveIRA DMT. 2011. Large plant samples: how to process for GMA embedding? In: CHIARINI-GARCIA HS AND MELO RCN (Eds), Light microscopy: methods and protocols, Totowa: Humana Press, p. 37-49.

PAREEK S, YAHIA EM, PAREEK OP AND KAUShIK RA. 2011 Postharvest physiology and technology of Annona fruits. Food Res Int 44: 1741-1751.

SvomA E. 1998a. Seed morphology and anatomy in some Annonaceae. Plant Syst Evol 209: 177-204.

Svoma E. 1998b. Studies on the embryology and gynoecium structures in Drimys winteri (Winteraceae) and some Annonaceae. Plant Syst Evol 209: 205-229.

TAIZ L AND ZEIGER E. 2010. Plant Physiology. Sunderland: Sinauer Associates Publisher, $782 \mathrm{p}$.

VARoguaux F, BLANVILLAIN R, DELSENY M AND GALloIS P. 2000. Less is better: New approaches for seedless fruit production. Trends Biotechnol 18: 233-242.

Zhang S, HuAng G, Ding F, He X And PA J. 2012. Mechanism of seedlessness in a new lemon cultivar 'Xiangshui' [Citrus limon (L.) Burm. F.] Sex Plant Reprod 25: 337-345. 